\title{
Application, Views, and Problems of Counselors Working with Syrian Elementary School Students
}

\author{
Feyza Nur Sinan*, Filiz Gültekin \\ Faculty of Education, Uludag University, Turkey
}

Copyright $\mathrm{O} 2018$ by authors, all rights reserved. Authors agree that this article remains permanently open access under the terms of the Creative Commons Attribution License 4.0 International License

\begin{abstract}
The war that began in 2011 caused many Syrians to immigrate. There are more than 2.9 million Syrian refugees in Turkey. With this unprecedented migration, Turkey has faced challenges in its education system as well as many other areas. The sudden increase in the number of students and the qualitative and quantitative insufficiencies of teachers are among some of these challenges. Teachers are forced to work with children who have undergone traumatic events and experience economic, familial, psychological, and vital problems. Additionally, these children are forced to adapt to a new language, culture, and education system. It is necessary to help these children adapt to the education system and provide the support they need. When fighting these challenges, school counselors play an important role for both teachers and students. In this context, the purpose of this study was to determine guidance services of counsellors regarding Syrian students, challenges, and views regarding these problems. The participants of this study consisted of 20 counselors working in elementary schools in Bursa. Data were collected with the semi-structured interview method in qualitative research methods and analysed with descriptive analysis. The results of this study indicated that counsellors struggle planning, although they are motivated to work with Syrian students. The largest obstacle faced by counselors is the fact that Syrian students do not know Turkish. The indifference of the parents of Syrian students and the high number of students also limit counselors. While offered psychological counseling and guidance (PCG) services focused on individual interviews and guidance to teachers, there is also work for the acceptance of Syrian students. The most important expectation is to prioritize to teach Turkish to students. It is believed that both Syrian students and their family, and other students and teachers will benefit from all improvements in PCG services by considering Syrian students.
\end{abstract}

Keywords Syrian Students, Counsellor, Elementary School

\section{Introduction}

Regardless of voluntary basis and distance, all migrations are made to achieve better living standards. However, where, and how immigrants will reach suitable conditions, what they will face on the journey, and when they will be locals rather than guests or foreigners are all uncertainties.

In simple terms, migration is different than dislocation. These terms include transition from one socioeconomic status to another, from one culture to another as individuals move to a new context by leaving behind the environment $\mathrm{s} / \mathrm{he}$ was born in and was/will be socialized in [1]. Migration should be considered in detail when children are included. Because changing physical and social environment described as "home" or "country" to children under the best circumstances means knowing what is unknown, learning what is different and losing what is accustomed [2]. According to Magwaza [3] children and adolescents are under greater risk compared to adults in terms of migration. This is because children need to fight against sudden change of migration and physical-mental development. Losing a home, which is supposed to provide safe shelter, friends, and other social environments, a feeling of security, close family members, school and a cultural loss due to leaving a socialized country, leads a traumatic life for children as refugees [4].

The needs of refugee children are highly complex and these children can easily be hurt in physical and psychological terms. Refugee children face unfamiliar and uncomfortable living conditions [5]. In addition to the economic problems, [6] these children need to live with anxious parents [7], and share problems of adults [8]. As it can be guessed, need of education is secondary after meeting primary needs. However, Sürüel [9] stated that accessibility to education, education resources and institutions can decrease the effects of other problems of immigrant children. The existence of a teacher-student relationship is important in terms of development of children [10]. Education has an important and effective role in protecting refugee and immigrant children [11]. 
School helps adapt to a country of asylum in cultural terms [5]. Receiving education, becoming successful in school, and making friends in school are among protective factors [12]. When the school environment of refugee children has positive properties, adaptation, sense of belonging, and academic success of students would increase [13].

Schools often act as communication points for refugee families and home countries, they lead to all shareholders, and discover news ways how schools can be structured, what are social norms and traditional and how those families can adapt to these elements [14]. Since teachers and counsellors are individuals who spend the most time with refugee children, they will be the first people to discover academic and psycho-social problems of students, take necessary precautions, apply interventions, and offer the necessary guidance [15]. In various studies that analyzed education levels of Syrian students in Turkey and problems related with education the following subjects were evaluated: trauma experienced by war, parent indifference, insufficient PCG services, problems caused by cultural differences [16], problems caused by adapting to education institutions [17], problems caused by insufficient knowledge of teachers regarding the education of refugee students [18], problems regarding access to education and participation [19]. Therefore, counselors play an important role for attendance of Syrian students, adaptation processes, forming healthy relationships with the environment, and intervening in trauma they are experiencing.

Teachers and counselors working in schools with refugee children and adolescents should have knowledge and awareness regarding psychological problems to meet the needs of these children [15]. School based application and interventions by school counselors are important to mitigate the school environment risks for mental health of refugee children and supporting protective factors [20]. Hence, studies emphasized that compliance with the environment, school, teacher and friends and interpretation of the change, psycho-social support to those children; raising awareness and knowledge for those children, education to families, culture, and compliance with city $[21,22,23]$ are important studies.

In this study, the work of counselors for Syrian students, problems faced by those counselors, PCG services needed by Syrian students and other groups, according to counselors' perspectives, and things to do regarding Syrian students according to counselors were investigated. Based on the data, the purpose was to determine insufficiencies in PCG services towards those children, the problems faced when offering PCG services, and needs of counselors. Based on this information, it is believed that PCG services offered to Syrian students at schools can be made more systematic and effective.

\section{Method}

\section{Research Model}

This study was designed in a qualitative pattern to determine and identify works and problems of counselors working in elementary schools with Syrian children. Qualitative research enables investigation of one subject or status in depth and in a holistic way [24].

\section{Participants}

This study was designed by using qualitative research and purpose-based sampling. In the qualitative researches, selecting the sample group compliant with the purpose of the study is among non-probabilistic sampling techniques [25]. The study was conducted in Bursa, which is the fifth largest city of Turkey. There is a large number of industries in Bursa. Thus, with its population of 3 million, Bursa is one of the cities in Turkey most exposed to internal migration. The study was completed with psychological counselors working in Osmangazi and Yildırım districts where the Syrian population is the highest. For the sake of data collection, the psychological counselors that the researchers were familiar with and that have Syrian students at their school were included in the study. After explaining the purpose of the study, face to face interviews were made with 20 volunteer counselors. 15 of the participants were female and 5 were male. The vocational experience of counselors varied between 1-18 years. 5 of them were in their first year of their profession; 5 had between 2 and 5 years of experience; 4 had between 6 and 10 years of experience; and lastly 6 of them have been working for more than 11 years. The number of Syrian students in their schools varied from 15 to 185 . At 8 schools, this number was less than 50 while at 4 schools it was more than 100 . The total number at schools varied between 500 and 1,850. And among the participant counselors, 14 are the only counselors at their schools.

\section{Data Collection Method}

The data for this study were collected with semi-structured interviews to determine information about counselor regarding Syrian students, what kind of work was done with Syrian students, what were they thinking about PCG needs of Syrian students and other groups, problems faced in the application, and their needs. Interview method enabled some advantages such as flexibility, higher answer rate, possibility to observe non-verbal behaviors, controlling the environment, changing the sequence of questions, knowing data source, completing data, and obtaining in-depth information [26]. Opening news subjects with different questions, talking about various subjects, and achieving new ideas about subject are possible with a semi-structures interview format [27].

One of the authors of this article works as a psychological counselor at a primary school at which Syrian students attend. In addition to the literature review, the author's experiences and observations were also taken 
into consideration while preparing the interview questions.

To test openness and compliance with the purpose, a pilot test was made with interview questions and the interview was restructured based on feedback. Counselors were informed about the research and time, and the date for interviews was determined for voluntary participants. Interviews were made by researchers and answers of the participants were recorded with an audio recording device in agreement with participants. Interviews took approximately 15-20 minutes.

\section{Data Analysis}

Content analysis was used for data analysis. The aim of content analysis is to discover concepts that will help explain the data. The data obtained with this method can be organized based on themes, or it can be presented considering the interview and observation questions or considering the related dimensions [24]. The themes in the study were organized on the basis of research questions. According to Bilgin [28], the content analysis technique requires objective reading principles in contrast to easy and automatic comment based on knowledge, intuition, attitude, values, and reference environment. In this study, audio records were transcribed by researchers on a computer environment. The study data were then encoded at different times. These encodings were compared and the common ones were determined. These themes were psychological counselors' acknowledgement levels about Syrian students, the services prepared specially for them, the challenges, future plans, Syrian students' psychological counseling and guidance needs, other students' psychological counseling and guidance needs and psychological counselors' expectations from the ministry. Direct citations were made so as to reflect the participants' opinions regarding these themes and sub-themes.

\section{Findings}

The findings of this study were organized around seven major themes. These themes were; information of counselor regarding Syrian students in their students, conducted works, obstacles, plans for the future, PCG services needed by Syrian students, PCG services needed by other students, and the expectations from ministry.

\section{Information of Counsellors Regarding Syrian Students in Their Schools}

In this theme, findings related to how well psychological counselors know Syrian students and how much information psychological counselors have about the students were included.

How Long Syrian Students are in Turkey

Psychological counselor that participated in this study stated that Syrian students started to enroll the school mostly four years ago and have been still coming.

My school had two groups of Syrian students. One group is Syrian students who came before the war which can talk Turkish and have higher socioeconomic levels without any war experience or trauma. However, there are children who were affected by the experience. There are also students who came there after the war in Syria. Most of them do not know Turkish. (PC 2)

I don't have knowledge about all of them, but if I would talk about the students I know, they have been attending to this school for three years. There are also students who arrived last year. (PC 7)

We have had Syrian students for four years. After the first year I started to work in this school, Syrian students started to come. First, there were few. But their number increased. (PC 10)

Now, there are not many newcomers. These students have been here for three or four years. These students can speak Turkish and tell their problem. But I have three or four problematic students. They have just come. Others can tell their problems, understand what we say, give feedback to us, and express themselves. (PC 11)

All are different. There are five years and two or three years. (PC 13)

When the events started, they started to come to our school. Maybe because the rents are affordable in this region, I don't know. We have Syrian students for a long time. And their number is increasing. (PC 16)

It depends on the students. Some have been here for a year, some are newcomers, and some have been here for three-five years. It is like that, it changes. (PC 20)

\section{Level of Turkish Language Skills}

Participants stated that depending on their time of arrival in Turkey, Syrian students have different levels of using Turkish; while some students use Turkish as their native language, others were unable to use Turkish.

We have had students for four years as well as newcomers. A level of using Turkish is better in $4^{\text {th }}$ grades and worse in $1^{\text {st }}$ grades based on class levels. It depends on when they arrived. (PC 4)

Some of the students have almost perfect pronunciation like a native Turkish student. We cannot distinguish some of Syrian students. (PC 5)

Their level of using Turkish is like this; some students can use the language as they play out on the streets and have been in Turkey for a long time. Some use the language well. (PC 12)

Half of them speak well and half of them struggle. 50-50. There are students who do not speak the language, they don't understand us, we communicate with movements. They are generally in the first grade. (PC 13)

For example, students in fourth grade learned as they came earlier. There are some who know nothing in fourth grade and there are some who speak like me. We are using 
those students to communicate with others. Other than that, students in first and second grade do not speak the language. Students in the second grade have different levels. For example, a shy student refuses to talk, maybe they understand Turkish, but we do not know. Because they show no reaction. But some speak well. If we consider the level of proficiency, it is varied. (PC 14)

In previous years, our Syrian students were using Turkish well. Students who came from the camps already learned Turkish there. But, some of the first-grade students have not yet learnt Turkish. It is because they have just come here. (PC 17)

There are some who do not know and some who can speak well. But the number of good speakers is low. If we have sixty, ten can speak and other barely speaks. (PC 18)

Little. I mean most of them do not know. Only four or five of them have learned Turkish. This is their third or fourth year. (PC 19)

\section{Life in Turkey}

Participants stated that most of the schools with Syrian students were in low socioeconomic level, students had large families, father and elder children worked, and sometimes younger children also worked.

Most of them have broken houses, problems with heating, economic problems, and families where everyone works including the children at home. (PC 2)

I mean they have bad economic conditions. They are paying rent. Their family works in constructions like mother and father. Sometimes the children tell that they also work outside like selling napkins, but there are no Syrian students with sufficient economic conditions (PC 3).

Now, their economic level is not that good. But I believe those students in our school can pay their rent or heating, etc. I mean I believe that have economy to survive. But of course, they certainly ask for any type of social aid in school. Like cloths. They want to benefit from that. (PC 6)

It is generally not good. They often get support. Lots of people stay in small houses, etc. But if those people were qualified back at home like teachers, or tailors, or have certain skills that they can work in a bakery, etc. They have a better economic level. (PC 9)

They are poorer than our poor students. They can continue living. I mean they have some sort of income. Their fathers work. Most of them have older brothers and they work... Mainly in the construction sector. Some of them help them with collecting paper, etc. This ... (district)... there are Syrians I do not know if you have noticed? They work in döner shops, fast food restaurants, cafes, and similar places. But there are lots of people in the textile. (PC 11)

Their life is like this; for example, I know that they live with large families. I know that they have lots of siblings. Other than that, some have a father at home, mothers of some are in Syria. Some have uncles here, they are distributed. I know that they have complex families that it is hard to tell who is who. Other than that, they have this structure; they are like the leader of the house. The mother takes the child to hospital since the child knows Turkish. She takes the child to hospital, they do their thing and ask for the sibling; so, the child does not come to school and goes with them. They complete their things they have this structure. (PC 14)

Actually, their economic levels vary. There are some in a bad situation and need help. Sometimes I see that some the students are selling socks with their families. Other than that, there are parents who have good income, bought houses and work as doctors or engineers etc. It is variable. (PC 16)

Actually, there is no problem as their needs are met by people around them and government. But some of our students who lost their father and living with their mother are experiencing economic problems. We are trying to tolerate this as the school. (PC 17)

There are good students, but most of them have low economic status. Some of the students are also working. For example, I saw during break one of them works with a marketer and helps him to sell potato or onions. We also talked with one of them and he is working in a bakery and trying to help. I mean most of the family members are trying to work. (PC 18)

Most of the Syrian students have multiple siblings. Most of them are forced to work. The father has to work, so do the children. (PC 19)

\section{Arrival Stories}

Most of the participants have no idea about arrival stories of Syrian students from Syria, some of these know the story of few Syrian students.

I know the story of few Syrian students. For example, the father of one of my students stays in Syria in war, and mother and four children including three siblings come to Syria and to Turkey and reach to Bursa. They stay in Bursa. They told me that they have some friends who have settled in Bursa. (PC 2)

We have fifty-three students, we cannot talk with all of them, but we generally talk with students we see. We talk about that they had different reasons to come here. They mostly talk that they escaped from war. Some of them lost some family members. Most of them has this, I believe they thought that "we should have fled to Turkey" before the war came to keep themselves safer. They have formed the idea to come here. But more than half of them witnessed the conflict. Some children lost their relatives. (PC 11)

For example, I remember I was touched by someone. One of my fourth-grade students experienced bombs and has traumatic experiences. The student was talking about it. The student said his father died and they came to Turkey. For some time, they lived with his grandmother in Antep and later came to Bursa. I know that. (PC 17)

Not all of them. Sometimes, they tell me, but through the teachers mostly. (PC 19) 


\section{Psychological Counseling and Guidance Services with Syrian Students}

This theme had findings regarding which PCG services were made by counselor regarding Syrian students.

\section{Individual Interview}

Participants focused on individual interviews. Most of the interviews were made with guidance of the class teacher. If students did not know Turkish, other Syrian students gave support.

We are meeting the parents of transferred students. I am asking them to come and see me if they have any problem. Other than that, if the children experience communication and adaptation difficulties, class teachers inform me, and I am trying to give support. I am trying to support children with interviews. (PC 5)

I am making individual interviews with newcomers and their family to learn more about them (PC 12)

There is this thing. In school, teachers guide to us. One of the main problems is tendency to violence. So, we are trying to take precautions against violence. Not as a group, but individually. I can see students who know Turkish... If they do not know Turkish we draw a picture. When you show them love and when they feel you are paying attention, they became happy and their tendency to violence decreases. We draw pictures, and hang them in class panels to make them happy (PC 13)

Other than that, when there is a problem, I am trying to have interviews. But I never can because they have problems expressing themselves. I am taking students who know. (PC 14)

Teachers are guiding the students who are experiencing problems if they know Turkish. I can listen to them. I listen to the problems and what happened. Other than that, there is not much work. Sometimes we make individual interviews, if teachers guide us. (PC 18)

But teachers guide me with a translator because we cannot communicate. (PC 19)

\section{Consultancy}

Participants stated that they were cooperating with school management and teachers in terms of Syrian students; they offered consultancy if teachers made such demand; they focused on class success and behavioral problems when teachers asked for help.

Some class teachers consulted.1st grade Syrian students do not understand what the teacher is asking in terms of communication. (PC 1)

Educational issues and adaptation related to the acceptance of other students in the class, and the inability of these students to adapt to the class. In addition, an examination of which grade level guides students they are being guided, but this orientation is ambiguous. When they come to the school, we must repeat the interviews with the teachers about what grade level they will be placed in and what they will do at that grade level (PC 2)
For example, there may be teachers who come to ask for help with their lessons. (PC 7)

When teachers have any problem about the Syrian students, we usually talk like this. (PC 8)

For example, in terms of identifying students who need economic support, the administration wants me to learn and talk to individuals or their families. They ask for help in determining their needs. Apart from this, if the teachers show behavioral problems on a class basis, if the students are excluded by their friends and cannot be included in the group, they want me to do some things in the class or to solve individual problems of students. (PC 17)

There are more consultancies to teachers, more activities which they can do, and picture activities to help these children to open their feelings... Teachers are already having counseling in every way about what they can do if they come in any trouble and say it. We are more teacher-focused. But, in this sense, teachers are trying to help the students more about their traumas related to their situation, which they should normally meet in some way in their behaviors. (PC 19)

\section{Works Regarding Acceptance of Syrian Students}

Participants state that they worked on attitude adjustment of some teachers and Turkish students regarding Syrian students.

We may be different, we should work together, we must do more work, and teachers must accept these students in their classes, children's positive perceptions of development, class differences in class work; because we try to create a sense of class. (PC 2)

We discuss with the students at the point of explaining the situation they lived with and approaching them accordingly. Exclusions, inclusion in the activities, using a discriminatory language, etc. because we see that "You are Syrian, go back to your country, what are you doing here." It could happen among students. We are interviewing with other students to prevent these. (PC 3)

I am trying to focus on individual differences... In our seminars we are trying to give information about individual differences like anger management, conflict solving skills, etc. (PC 15)

Because there are problems among Turkish students with Syrian students. Sometimes we see exclusions. This is not all about children, families also contribute. Some families tell their children not to talk with the Syrians. Students tell us "my mother does not want me to talk, my father does not want me to play", etc. We also made a meeting with those parents. We are giving them seminars and information. Game of children became violent games related to peer relations ( $P C 19)$.

\section{Other Works}

Other works of the participants consisted of home visits, creating brochures, family meetings, and orientation.

For now, they only attended to the orientation program 
to know the school and students. (PC 1)

When necessary, we can make home visits in collaboration with school family union and school management... I invite families. We distributed brochures to the parents. The problem with parents is language. We distributed brochures, introducing Bursa, explained things about it. (PC 12).

We, as guidance service, printed Arabic brochures about school rules. (PC 19)

\section{Obstacles}

In this theme, findings regarding obstacles with Syrian students, and status, people, and subjects that made working with Syrian students hard or impossible.

\section{Language Barrier}

Participants were asked what obstacles they faced while working with Syrian students. Most of the participants stated language as a barrier.

Due to language barrier, I cannot do most of the work. For example, I would like to work on trauma of these children. Other than that, I want to make family education just for the family of these children. But language is an important barrier. Walking with teachers or students who know Arabic or Kurdish on school corridors is desperate. (PC 2)

Since we cannot communicate, we cannot do most of the things. We are trying to communicate with online translation programs, or we are asking for students who know Turkish to translate. Since we work like this, we do not have many events. (PC 3)

We could not do it, although we saw the need, because we have a primary communication problem. I wanted to teach them not to show reaction to an action. I wanted to prevent them from attacking when they see a small action. But we could not do it. Since they have not learned Turkish, we have problems with vocabulary we use. (PC 10)

I see the language as a barrier. (PC 14)

For parents, the most important barrier is language because they sometimes come with someone else like their neighbor. This causes them to avoid us. (PD 12)

I hoped to help for adaptation more when they come to school. I do not think I am effective for adaptation to school or consulting. Most problems are with trauma. But language is a barrier at this point. It is the biggest problem. I tried to orient them from the side so that they could embrace them at least from the other side of the class with activities done in the classroom, but as I said, it was not very effective, and I was not as helpful as the others. (PC 19)

\section{Inability to Reach Parents}

Some participant stated that being unable to reach parents were barriers for Syrian students. Only a handful of Syrian parents have individual referrals to the guidance service, usually to the school for official work and assistance requests.

Parents. We tried a couple of times. One parent showed up. The other one didn't come because the father worked... Some things may change if we reach out to Syrian parents. Maybe they experience less violence, or someone paid attention. They may not be able to help with the lesson, but I think a head caresses a carnal soul, but we cannot give these trainings to the family. (PC 11)

We have problems to reach to parents. (PC 14)

They never showed up. Most of them come to get some material, i.e. support, to get help, but they come to get help, but no parents came to ask me any questions (PC 7)

They never come. I have never talked to a Syrian parent. They only come to administration for records. Then, they don't care. (PC 8)

\section{High Number of Students}

Participants stated that they did not have enough time as the number of students was high.

They are one of the groups that need counseling, but we don't have time. (PC 13)

Maybe we could do something if we didn't have 940 students. I can work on some, but it is impossible for now. (PC 7)

Maybe I can organize more events for them to be loved and accepted by other students. But I don't have much time for this. The school is crowded and most of the time I don't have time for this (PC 18).

\section{Plans for the Future}

This theme has findings regarding which PCG services will be made by counselor regarding Syrian students in the future. Interviews showed that most of the participants have no plan regarding guidance services offered to Syrian students. Participants who claimed planning stated that there was no schedule and subjects were varied.

I am planning seminar work for teachers during seminar period. First, I believe that we should teach teachers how they will do the class and how they can be sensitive to that culture. Teacher works should be made. (PC 2)

We looked at whether we should do a psychosocial application for them, but they don't understand Turkish well. They lost the subject with a lot of psychology-related talk (PC 10).

Our major problem in school is that they are constantly harming something. I am planning to gather them and give positive behavior education. (PC 13)

I am thinking about interviewing teachers because they have some idea. I can interview with them and identify the students that I should meet in person (PC 14).

There are lots of things to do. But since we really have problem with Turkish, we cannot do many events. (PC 16).

I guess counselor friends in Bingöl said that they translated psycho-education work to Arabic and applied to 
Syrian students. I was very excited to get it from them, but it was a study that I couldn't put into practice because I didn't have much time to apply it, and there is no Arabic speaker teacher in the school. But if I see such things again in the coming years, at least I want to do this work with these students from the very beginning. (PC 17)

I never planned. But after learning Turkish and speak Turkish better, we may do some work. But I don't believe it will be specific to them. I will include them in a class environment. I don't think I will have time for specific events. Like this. (PC 18)

I want consultancy with their group. But since language is a problem, if I work with students without the language barrier, I can also have an impact on their trauma. (PC 19)

I am waiting for them to learn the language this year. But next year I will give the same number of seminars to them as the other students. (PC 20).

\section{PCG Services Needed by Syrian Students}

This theme indicates the views of participants regarding PCG services needed by Syrian students. In the light of the findings, participants seem to think that Syrian students mostly need personal-social guidance services.

In particular, it is necessary to have a few weeks of orientation before the school begins. Courses for reading comprehension, school rules, behaviors plus reading and writing for non-language learners need to be done. Before coming to the school environment, students who may be in the summer may need to go through a literacy process. At the point of orientation, the guidance counselor of the school or a psychological counseling group to engage can carry out this work. Universities and academics can also make a project at this point. (PC 3)

They have problems with hygiene. (PD 6)

Perhaps because they have migrated from one place to the next, what can be done to recognize the culture of that place in every sense, to integrate them more in the sense of recognizing and adapting? It is more likely that children can participate in common activities together with social activities. More common games can be created, for example. There are things that will increase the share more; team games etc. This can be done in this way. (PC 9)

First of all, what I have observed is violence, anger control, they have to learn. They are getting better. But there is still violence. And their way of communication, a little bit different. So, it is not enough to talk quietly or use communication skills properly. They are aggressive. (PC 11)

First, adaptation and orientation. I think guidance teacher should work on trauma as they came from a war. (PC 13)

I believe Syrian students have problems in expression their emotions and controlling their emotions. They came from war, so anger is normal, they had a good life, but they had to separate from it. Now they have a bad life. (PC 14)
Generally, hygiene. Maybe their relationship with their friends. In general, peer pressure, anger control, and communication skills, productive study, perhaps in fact, as we have already given to our hungry students, may be a little more difficult because they have difficulty with the language. I believe these should be provided in general. (PC 15)

There are lots of behavioral problems. Works should be done for behavioral problems because they have great violence tendency. I don't know if it is because they are excluded to them see themselves like this, they are forming groups, especially boys make groups and attack to other students. They need sexual education because they are active. (PC 16)

They are now starting the school by adapting to our education system. Their purpose is to learn Turkish. First, I think that their needs need to be met in an educational sense... All of these children have a traumatic experience. Even the most non-problematic one is coming from a war environment and it comes with consciousness. Here, too, the student is somewhat out of the community. Therefore, I think that it is necessary to have a study to deal with traumas with the support of psycho-education, certainly for the families and children. (PC 17)

There may be educational guidance; because they can experience difficulties in terms of course planning, and they can also experience difficulties in terms of course work. As I said before, there are some that are forced to work. Some of them have this priority. Maybe educational guidance can be planned for them. (PC 18)

Actually, they need what Turkish students need. They are also children. These children need the same things in the same way as other children, whether related to other peer violence, friendships, communicating, privacy education, or anything else. Because the extras are only exposed to trauma, it is in fact necessary that this is done at the very beginning. All other studies need to be applied to these children. (PC 19)

\section{PCG Services Needed by Other Groups with Syrian Students}

Counselors were asked if they need to work with other groups for Syrian students and what type of group is needed if necessary. Participants stated that Turkish students and parents, Syrian student parents, and teachers should be included.

\section{Needs of Turkish Students and Turkish Parents}

Some of the participants stated that Turkish students attending to same classed as Syrian students, and parents of these students might have problems with acceptance, therefore, Turkish students and parents should be informed about sensitivity to differences.

Other students may see as they are Syrians. Exclusion or comparison may happen. Education and events could be 
organised not only for Syrian students, but also for other students. Instead of seminars, events could be simplified for students to understand. (PC 15)

Actually, something could be done for Turkish students to understand Syrian students. But the number of Turkish students is higher. I don't know how it could be done. Something could be done for them to understand others and be more compassionate; because we have some harsh students due to their families. Not all of them, but there are some. This creates negativities like fights. (PC 16)

I would like to give education to parents to communicate with other parents and change the perspective of students because students fail to accept other at first. Those students are perceived as the root of problem in Turkey and children believe this as well. (PC 2)

Unfortunately, there is a negative perspective towards Syrian children, especially among parents. I am emphasising this in individual parent interviews or parent trainings. But I believe this should be explained more. (PC 12)

\section{Needs of Syrian Parents}

Some of the participants stated that they needed knowledge regarding education application in Turkey for Syrian parents and editing responsibilities and behavior of parents in these processes.

We can achieve more participation from parents. Not most of the mother-fathers are interested. Mothers are mainly at home; they deal with home and rarely come to school. Fathers constantly work due to economic worries. Maybe work towards mother-father interest can be done. (PC 5)

I don't believe parents have knowledge about our education system. I may give information about what can be done, how Turkish parents contribute to the education of the children, and what are their responsibilities regarding education. (PC 17)

But in terms of parents I think parents should be educated. But the first language problem should be solved. This could about gaining positive behaviour. (PC 20)

Needs of Teachers

Some of the participants stated that teachers needed information about how to meet the needs of Syrian students.

First, I believe that we should teach teachers how they will do the class and how they can be sensitive to that culture. Teacher works should be made. (PC 2)

We can support teachers in a more functional way, even if we may not add new things. We can tell them how they should work and how they should teach, and increase awareness of parents, we can benefit from that. (PC 17)

\section{Expectations from Ministry of National Education}

Participants were asked what kind of adjustment should have been made by ministry and what they expected from the ministry for Syrian students

\section{Language Education}

Most of the interviewed counselors stated that Turkish works should have been reshaped for Syrian students primarily.

I think language problem of the children should be solved. After the language problem has been solved, they should be transferred to our schools. (PC 4)

I think they should have had language education for one year. For example, the child is in the third grade, he should first only have Turkish language education, learn more about Turkish traditions and beliefs and come to school. I think this will be beneficial. And it will be good in terms of orientation. They will learn the language and culture; because teachers struggle when they should teach the class, culture, or language. (PC 6)

If they don't know the language they need to learn to express their own problems and conditions. (PC 9)

I think language problem should be solved first... No matter how intense we apply preventive actions they are incomplete as we fail to reach Syrians. (PC 13)

...Other than that, they would feel safer if there are people who know Arabic. If I have a problem, I can express myself to that person in detail. Nothing will be like mother tongue. (PC 14)

In fact, I think maybe one year, at least the first year, the first year of the year instead of merely classrooms, instead of intensive study of Turkish and literacy work. You have to do this all together; because something like this happens, some can be adapting, but some are starting to get in trouble if they cannot be adhered to. At least I think that they should read and write intensively in the year they first came to Turkey and then come here after being taught. (PC 16)

I think that these children should be taught in a separate school starting from the first year of primary education. They cannot get on with the students. The teachers do not understand them. These children only sit in class; they get bored, and gain nothing. So, when they are in pre-school age, they should start to learn Turkish and when the children learn Turkish, they can go to the same school with Turkish students. (PC 18)

\section{Collecting in One School}

Some of the participants stated that it would be better to collect Syrian students in one school at least until they learn Turkish.

Maybe to give education for each level, it would be better to have private schools for them because we don't have enough time to pay special attention to these students who are in the same class with students with certain academic level. If private classes or schools for Syrian students are formed, we can contribute to their education. (PC 5) 
The healthiest solution for me is to collect these students and families in one center. One building. This way, students will be educated in their own culture in a healthy education process by their teachers. (PC 10)

Now, we need to think both sides. Maybe they are receiving education in a language they do not understand and stay behind the class. They are getting mixed, but they have no academic gain. Wouldn't it be good to do something about it with experienced teachers who know Arabic? (PC 11)

\section{Other Expectations}

Other works in ministry levels were economic support, creating activity areas, more attention from teachers, and achieving social acceptance.

We may make their socioeconomic levels, etc. better. I think this will be it. (PC 4)

First, economic problems play a more important role than academic skills of children. The ministry should provide clothing and housing. (PC 15)

They need more activities than this. What could those be? They need an indoor gym. At the end of each corridor corner with Mangala sets, chess sets, and table tennis could be supplied. This would be really good. Students can engage with these instead of harming each other. This would help eliminate violence. There is this thing; as I said language has negative effects. This could be neutralising because they don't need to talk. While playing chess, check, or Mangala, the child doesn't need to talk and can easily make friends. I think this could help them. (PC 7)

Maybe, our teachers may focus on this more. The thing isn't excluding them or not paying attention. They could pay more attention and work with them as their own students. Education-training could be given at the highest level. (PC 8)

In a general sense, I believe our perspective should be changed like this. You asked me that what should be done with Syrian students. First of all, if we accept that our children and sisters as parents and administrators can come to us in this way, we have a different negative point of view towards the students of Syria, especially parents... because we need to accept those children. We cannot make progress by excluding or disregarding. Students who are excluded from the society or school will not form a healthy relationship no matter how many individual interviews you make. (PC 12)

Students are spending time at school, but when they are outside, they are in a different culture they do not belong. So, it would be good if they could be included in socialising environment outside school. (PC 17)

If people working with these children were experts who understand their psychology or language, it would surely be more effective. But when we look at it, there are serious works in this matter... There are unique works in Turkey... Steps are taken for these students and their parents, and support is given. (PC 19)
Family education can be given (to Syrian parents). This could about gaining positive behavior. (PC 20)

\section{Discussion and Comment}

In this study, information such as information regarding Syrian students, how long Syrians students are in Turkey, level of Turkish language, their lives in Turkey, and arrival stories to Turkey of counselors were obtained. According to Yeşilyaprak[29], correctly identifying the needs of the target audience and constantly evaluating those needs is the first step of effective PCG program. Based on these findings, it could be stated that counselors failed to accomplish any analysis to identify the needs and evaluations were mostly based on non-systematic observations and interviews. The reason counselors failed to use individual knowing techniques to learn more about Syrian students and identify their needs could be the language barrier which posits a problem about how to directly collect information. On the other hand, systematic observation technique or structures teacher vies could be used for obtaining information about Syrian students. The reasons counselors avoided these methods could be related with not having enough time for Syrian students and applying these methods or unable to predict which preventive strategies to use when they obtain such information. When information was collected, it is possible to see various situations that will need coping with traumatic life and intervention and this could be frightening.

When PCG services with Syrian students at school were considered, it was visible that services mainly focused on individual interviews. Most of these interviews were limited to guidance of teachers and students who are able to communicate. An important portion of guidance services consisted of consultancy services to teachers. Şensin[30] stated that class teachers needed various supports including support from translators. Er and Bayındır[18] reported that most of the teachers $(74.7 \%)$ stated that they had no knowledge about educating refugee students in the study to evaluate pedagogical approach of class teachers. Additionally, it was determined that the education of refugee students would have problematic aspects. In this study, it was determined that teachers asked for help from counselors in terms of class success and behavioral problems.

Counselors stated that they sometimes worked for social acceptance of Syrian students by Turkish students and parents, but they also stated that they needed more work. Bugay, Karakedi, and Erdur-Baker[15] explained that counselors should enable communication between students from different cultures and develop a communication method where they can learn from each other. It was clear that counselors had no additional work for social acceptance of Syrian students and they mainly use in-class 
activities, seminars, meetings, or interviews. Achieving social acceptance of Syrian students will contribute to the common life culture of Syrian students, Turkish students, teachers, and parents as well as supporting education in harmony.

When the obstacles were identified, all counselors stated the biggest obstacle was the language. Various studies emphasized the problems experience due to insufficient use of language by immigrant children. [19,31,32]. MercanUzun, and Bütün[17] stated that as Syrian children had no knowledge of the Turkish language, they failed to communicate with peers and teachers, thus, they failed to socialize and excluded from the group. Counselors stated that they were facing with the language barrier when they wanted to work with Syrian students and parents. Another obstacle was unable to reach parents. Studies indicated that parents of immigrant children were unable to show necessary interest to their children [16,33,34]. Roxas[35] stated that language insufficiencies of parents and inability to know what to expect from school, they failed to participate in school activities. In this study, counselors stated that both Syrian parents and education applications in Turkey and responsibilities in this process should have been informed about child development, behavior management methods, and psycho-education. Insufficient time and high number of students were among other obstacles. Average number of students in schools that counselors worked was 787. However, it was projected that a counselor who will be working in primary schools will be able to serve between 300 and 500 students in Regulations Regarding the Norm Staff of Administrators and Teachers of Educational Institutions affiliated to the Ministry of National Education [36]. Therefore, it could be stated that counselor fails to spend enough time for services regarding Syrian students or their needs. Similarly, not having works about acceptance of Syrian students and parents by Turkish students and parents could be explained with this obstacle.

It was clear that counselor had plans about Syrian students but have no scheduled plan in this sense and Syrian students were excluded from School PCG Service Annual Plan.

When needed PCG services were investigated, it was observed that needs of different groups were different. Based on the views of counselors, services needed by Syrian students were focused on individual-social field. While Syrian parents needed information about responsibilities about being a parent and behavior correction methods, Turkish students and parents needed information about sensitivity for differences. However, these works could lose effectiveness if carried out only under the acceptance of Syrian students. For this purpose, the scope of these works should be larger and should have an approach to accept all differences under respect.

Expectations of counselor regarding Syrian students were about learning Turkish and at least staying in the same school until they learned Turkish. Yiğit[34] asked teachers about their views about separate school for refugee children and school managers. Most of the teachers and school managers stated that separate schools were beneficial and most of the children stated that their parents wanted multi-cultural classes. Ministry of National Education is offering adjustments to give education to all students together. During November 2016, 3625 Turkish teachers were employed and during March 2017, 1843 Turkish teachers were employed to teach and educate Turkish in the schools and institutions where Syrian students are in the scope of "Project for Supporting the Integration of Syrian Children into Turkish Education System" (PICTES). A total of 5,468 Turkish Teachers is working in the province of Bursa [37]. Other expectations were economic support, creation of activity areas, more interest of teachers, and the provision of social acceptance.

\section{Results and Recommendations}

In line with the findings of this study, according to counselors, Syrian students and parents, Turkish students and parents who are in the same class with Syrian students, class teachers with Syrian students required different PCG services. However, due to language barrier and high number of students in schools, counselors fail to give additional time to Syrian students. In this sense, with the Turkish Psychological Counseling and Guidance Association or Guidance and Research Centers, social media groups that will enable to share works, applications, and information for those students could be formed. This way, peer support to counselors could be provided to work with these students and effective services could be delivered.

Guidance and Psychological Counseling Services Plan Preparation Booklet published by the Ministry of National Education, General Directorate of Special Education and Guidance Services in 2017 stated the general level target set out by the Ministry of National Education of guidance plans is to be prepared at the local level as determined by the PCG Services Provincial Advisory Commission and at the specific level to be determined by the schools. In this sense, when guidance plans are created, guidance activities for Syrian students and their families could be placed in one of the general, local, or private targets determined by the ministry.

Creating a detailed PCG service plan for Syrian students and parents could increase the quality of the services. This plan can include education practices in Turkey, responsibilities, and behavior modification methods as parents in the educational process; school rules, hygiene, adaptation to school and environment, trauma, anger control and expressing emotions, communication skills, friendship relationships and behavior problems.

Applications such as Syrian parents taking an active role in schools' parent-teacher associations, Syrian students 
actively participating in school student council could be effective on social acceptance of students and parents. Informing Turkish students and parents about immigrant and refugee laws, and children law could help them evaluate the subject in a wider perspective, notice them that such rights are given due to their situations rather than prerogative, thus, help them accept Syrians.

In-service trainings that can be given to the Ministry of National Education on issues such as orientation skills, immigration psychology, psychological first aid, mourning and trauma and working skills can enhance the quality of guidance services. These trainings could increase the service directly given to students and services given to teachers as counselors.

One of the most important problems when working with Syrian children was the language barrier. Multicultural counseling skills in undergraduate and postgraduate training programs, in-service training programs, as well as game therapy and art therapy training can be given. Also, drama, games, painting, etc. skills could be given. With such non-verbal activities, it could be possible to establish relationship with children, learn more about them and guide them. Uğurlu[38] worked with refugee children and stated that art therapy is an effective way to decrease post-traumatic stress disorder, depression, and childhood anxiety symptoms.

Additionally, to strengthen the communication of parents with school and to make knowledge taking from guidance services easier, Turkish and Arabic printed material could be developed.

For future studies:

While this study was being conducted, Ministry of National Education started Turkish language education for Syrian children and parents. Therefore, after overcoming Turkish language barrier which is one of the most important obstacles for PCG services, researchers that will have an effect on providing PCG services could be determined.

Empirical studies may be conducted to determine whether providing peer support for studies with Syrian children is effective in increasing the quality and quantity of services provided by counselors.

Based on the language barriers, studies can be conducted on the effectiveness of guidance activities that involve less language skills such as painting, music, and creative drama for these children.

In this study, the opinions of counselors about the PCG needs of Syrian students were determined. Parents', teachers', administrators', and students' opinions are required to determine the needs precisely. In this context, the opinions of Syrian students, Turkish students, Syrian parents, and Turkish parents can be researched.

\section{REFERENCES}

[1] Kilıçaslan, S. C. (2014). Sosyal hizmet ve öteki disiplinler arası yaklaşım, Pınar Akkuş-Özgür (Ed.), İstanbul: Bağlam Yayınc1lı.

[2] Özer, A. (2015). Göç ve aidiyet bağlamında Bulgaristan göçmenlerinde kimliğin yeniden inşasi: Mersin örneği. (Unpublished master's thesis), Mersin University, Mersin, Turkey.

[3] Magwaza, A. S. (1993). Migration and psychological status in South African black migrant children, The Journal of Genetic Psychology, 155(3), 283-288.

[4] Güneş, G. (2012). Çocuk hakları açısından Türkiye'deki sığınmacı çocuklar: Çeçen çocukları örneği. (Unpublished master's thesis), Yalova University, Yalova, Turkey.

[5] UNHCR (1979). The refugee child- UNHCR protects for refugee children international year of child. https://www.unicef.org/about/history/files/Child-Nation-M -Black-Ch15-p353-377-year-or-child.pdf. Erişim Tarihi: 22.10.2017

[6] Erdoğan, O. (2011). Çocuk haklari. İstanbul: Seçkin Yayıncilik.

[7] Ajduković, M., Ajduković, D. (1993). Psychological well-being of refugee children. Child abuse and neglect, 17(6), 843-854.

[8] Çorabatır, M. (2006), Mülteci ve sığınmacı çocuklar daha fazla destek bekliyor, Sivil Toplum Dergisi, 4 (16).

[9] Sürüel, T. (2008). Göç ve sosyal dışlanma ilişkisinin sosyal politika açısından analizi (İstanbul-Sultanbeyli örneği), (Unpublished master's thesis), Kocaeli University, Kocaeli, Turkey.

[10] Gander, M. J., Gardiner, H. W. (1995). Çocuk ve ergen gelişimi. Ankara: İmge Kitabevi.

[11] Suriye'den İstanbul'a Gelen Siğınmacıları İzleme Platformu, (2013). Yok sayilanlar: Kamp dişında yaşayan Suriye'den gelen sığınmacılar İstanbul örneği. http://www.ihd.org.tr Erişim Tarihi: 10.09.2017

[12] Rutter, J. (2006). Refugee children in the UK. McGraw-Hill Education (UK).

[13] Şeker, B.T., Aslan, Z. (2015). Eğitim sürecinde mülteci çocuklar: Sosyal psikolojik bir değerlendirme, Kuramsal Eğitimbilim Dergisi, 8(1), 86-105.

[14] Rah, Y., Choi, S., Nguyễn, T. S. T. (2009). Building bridges between refugee parents and schools. International Journal of Leadership in Education, 12(4), 347-365.

[15] Bugay, A., Karakedi, G., Erdur-Baker, Ö. (2016). Kriz danışmanlığı. Ö. Erdur-Baker ve T. Doğan (Ed), Zorunlu göç ve mülteci psikolojisi (361-398). Ankara: Pegem Akademi.

[16] Arabacı, İ. B., Başar, M., Akan, D., Göksoy, S. (2014). An analysis about educational problems in camps in which Syrian refugees stay: Condition analysis. International $J$. Soc. Sei. \& Education, 4(3), 668-681.

[17] Mercan Uzun, E., Bütün, E. (2016). Okul öncesi eğitim kurumlarındaki Suriyeli sığınmacı çocukların karşılaştıkları 
sorunlar hakkında öğretmen görüşleri. Uluslararası Erken Çocukluk Ë̆itimi Çalışmaları Dergisi, 7(1), 72-83.

[18] Er, A. R., Bayındır, N. (2015). İlkokula giden mülteci çocuklara yönelik sinıf öğretmenlerinin pedagojik yaklaşımları. Uluslararası Sosyal ve Ĕgitim Bilimleri Dergisi, 2(4), 175-185.

[19] Emin, M. N. (2016). Türkiye'deki Suriyeli çocukların eğitimi; Temel eğitim politikaları. İstanbul: Seta.

[20] Döner, H. (2016) Irksal/etnik azınlıklarla üç boyutlu psikolojik danıșma modelinin göçmen çocuk ve ergenlerle çalışma sürecinde kullanımı, VI. Ulusal PDR Uygulamaları Kongresi 1-3 Aralık 2016, Gaziantep.

[21] Tok, N. (2010). Göç alan okullarda ilköğretim 4. ve 5. sınıf öğrencilerinin rehber öğretmen ve sınıf öğretmenlerinin görüşlerine göre öğrenme güçlüklerinin incelenmesi. (Unpublished master's thesis), Mersin University, Mersin, Turkey.

[22] Atasü-Topcuoğlu, R. (2012). Türkiye'de göçmen çocuklarin profili, sosyal politika ve sosyal hizmet önerileri hizli değerlendirme araştirmasi. Ankara: Uluslararası Göç Örgütü Yayını.

[23] T.C. Nevșehir Valiliği İl İnsan Hakları Kurulu. (2016). Geçici Koruma Altındakiler, Sığınmacılar, Göçmenler ve Mülteciler Raporu, Nevşehir.

[24] Yildırım, A., Şimşek, H. (2006). Sosyal bilimlerde nitel araştırma yöntemleri. Ankara: Seçkin Yayıncılık.

[25] Marshall, C., Rossman, G.B. (2006). Designing qualitative research. California: Sage

[26] Karataş, Z., Yavuzer Y. (2015). Bireyi tanımada test dışı teknikler. Ankara: Nobel Yayınc1lık.

[27] Merriam, S. B. (2013). Nitel araştırma: Desen ve uygulama için bir rehber. Ankara: Nobel Yayıncılık.
[28] Bilgin, N. (2014). Sosyal bilimlerde içerik analizi. Ankara: Siyasal Kitabevi

[29] Yeşilyaprak, B. (2015). Ĕgitimde rehberlik hizmetleri. Ankara: Nobel Yayıncılik.

[30] Şensin, C. (2016). Sınıf öğretmenlerinin Suriye'den göçle gelen öğrencilerin eğitimlerine ilişkin görüşlerinin değerlendirilmesi. (Unpublished master's thesis), Uludağ University, Bursa, Turkey.

[31] Buz, S. (2002). Türkiye'deki sığınmacıların üçüncü bir ülkeye gidiş için bekleme sürecinde karşılaştıkları sorunlar, (Unpublished master's thesis), Hacettepe University, Ankara, Turkey.

[32] Beter; Ö. (2006). Sınırlar ötesi umutlar: Mülteci çocuklar. Ankara: Sabev.

[33] Deveci, A., Gürbüz, H. B. (2012). Educational and administrative problems encountered at schools by Turkish students in Denmark, Procedia - Social and Behavioral Sciences, 46, 5805-5810.

[34] Yiğit, T. (2015). Uygulamalar ve sorunlar bağlamında Türkiye'de sığınmacı çocukların eğitimi (Kırşehir ve Nevşehir örneği), (Unpublished master's thesis), Ahi Evran University, Kırşehir, Turkey.

[35] Roxas, K. (2011). Tales from the front line: Teachers' responses to Somali Bantu refugee students. Urban Education, 46(3), 513-548.

[36] http://mevzuat.meb.gov.tr/html/normkadro_1/yonetmelik.p df. Erișim Tarihi: 13.10.2017

[37] https://pictes.meb.gov.tr/izleme/Faaliyetler/TurkceOgretim i. Erişim Tarihi: 22.10 .2017

[38] Uğurlu, N. (2015). Outcome of art therapy intervention on trauma, depression and anxiety symptoms among Syrian refugee children. (Unpublished master's thesis), Bahçeșehir University, İstanbul, Turkey. 